\title{
Updated consensus statement on the use of rituximab in patients with rheumatoid arthritis
}

\author{
Maya H Buch, ${ }^{1,2}$ Josef S Smolen, ${ }^{3,4}$ Neil Betteridge, ${ }^{5}$ Ferdinand C Breedveld, ${ }^{6}$ \\ Gerd Burmester, ${ }^{7}$ Thomas Dörner, ${ }^{7}$ Gianfranco Ferraccioli, ${ }^{8}$ Jacques-Eric Gottenberg, ${ }^{9}$ \\ John Isaacs, ${ }^{10}$ Tore K Kvien, ${ }^{11}$ Xavier Mariette, ${ }^{12}$ Emilio Martin-Mola, ${ }^{13}$ Karel Pavelka, ${ }^{14}$ \\ Paul P Tak, ${ }^{15}$ Desiree van der Heijde, ${ }^{6}$ Ronald F van Vollenhoven, ${ }^{16}$ Paul Emery; ${ }^{1,2}$ for \\ the Rituximab Consensus Expert Committee
}

For numbered affiliations see end of article.

- Supplementary material is published online only. To view these files please visit the journal online (http://ard.bmj. com).

\section{Correspondence to}

Professor Josef S Smolen, Department of Internal Medicine 3, Division of Rheumatology, Medical University of Vienna, Waehringer Guertel 18-20, A-1090 Vienna, Austria; josef.smolen@wienkav.at

The first two authors contributed equally.

Accepted 10 January 2011 Published Online First 6 March 2011

\begin{abstract}
Background Since initial approval for the treatment of rheumatoid arthritis (RA), rituximab has been evaluated in clinical trials involving various populations with RA. Information has also been gathered from registries. This report therefore updates the 2007 consensus document on the use of rituximab in the treatment of RA.

Methods Preparation of this new document involved many international experts experienced in the treatment of RA. Following a meeting to agree upon the core agenda, a systematic literature review was undertaken to identify all relevant data. Data were then interrogated by a drafting committee, with subsequent review and discussion by a wider expert committee leading to the formulation of an updated consensus statement. These committees also included patients with RA.
\end{abstract}

Results The new statement covers wide-ranging issues including the use of rituximab in earlier RA and impact on structural progression, and aspects particularly pertinent to rituximab such as co-medication, optimal dosage regimens, repeat treatment cycles and how to manage non-response. Biological therapy following rituximab usage is also addressed, and safety concerns including appropriate screening for hepatitis, immunoglobulin levels and infection risk. This consensus statement will support clinicians and inform patients when using B-cell depletion in the management of RA, providing up-to-date information and highlighting areas for further research. Conclusion New therapeutic strategies and treatment options for RA, a chronic destructive and disabling disease, have expanded over recent years. These have been summarised in general strategic suggestions and specific management recommendations, emphasising the importance of expedient disease-modifying antirheumatic drug implementation and tight disease control. This consensus statement is in line with these fundamental principles of management.

A recent advance in rheumatoid arthritis (RA) has been the introduction of B-cell depletion as a therapeutic modality. Rituximab, a chimeric anti-CD20 monoclonal antibody is the currently available, licensed B-cell depleting agent, with several studies supporting the efficacy and acceptable safety profile of this approach. ${ }^{1-3}$ To address the benefits, limitations and safety concerns of its application, a consensus statement on the use of rituximab in patients with RA was formulated in 2006. ${ }^{4}$ Since then a large amount of new information has become available, with new insights into both the efficacy and the safety of B-cell depletion with rituximab.

Therefore, an international group of experts and patient representatives mainly from Europe experienced in clinical research, the use of biological agents and the development of recommendations, convened in Amsterdam in May 2010 to revise the consensus statement. The members of the original expert group were re-invited to participate and, in addition, more recent contributors to the field primarily based on the original publication. The steering group, consisting of MHB, JSS and PE had full control over the invitations.

This update will concern the following areas:

- Mode of action

- Indication, considerations and screening for initiating rituximab in RA

- Treatment dose algorithm and co-medication

- Evaluation and management of response as well as lack of response and considerations for retreatment

- Predictive factors of response

- Contraindications and adverse events (AE)

- Long-term exposure-efficacy and safety issues

- Research agenda

Importantly, we have on this occasion placed greater emphasis on the patient perspective.

To achieve our objective, a systematic literature review of the published literature on the efficacy and safety of rituximab in treating patients with RA was first undertaken (MHB) to identify relevant data and information (details included in the supplementary material, available online only).

The outcome of the discussion of the new data and results of this activity will be presented in this publication. Categories of evidence will be indicated next to each reference in line with published guidelines (Table 1); ${ }^{5}$ assignment of the Ia category was agreed to require the availability of two or more randomised controlled trials (RCT) with similar results.

Significant amounts of data have been generated and discussed, all of which could not be included within this document but have instead been added in the supplementary material available online only.

\section{MECHANISM OF ACTION OF RITUXIMAB IN RA}

Rituximab targets the CD20 molecule, which is expressed on the surface of B cells from pre-B-cell through memory B-cell stages ${ }^{6} 7$ but not on stem 
cells and pro B cells nor on plasma cells/blasts. Rituximab leads to transient but almost complete depletion of $\mathrm{B}$ cells in the blood and only partial depletion in the bone marrow ${ }^{8-13}$ and synovial tissue. ${ }^{14-16}$ Response has been shown to correlate with the level of synovial membrane B-cell depletion ${ }^{9}$ and early peripheral blood depletion of B cells measured by sensitive assays, ${ }^{9}$ possibly useful as a surrogate. It also frequently induces a reduction of immunoglobulins, notably IgM ${ }^{17} 18$ (see supplementary material, available online only, for more detailed discussion).

B-cell repopulation studies following rituximab treatment suggest reconstitution with antigenically inexperienced, transitional B cells derived from an immature population. ${ }^{8}{ }^{19}$ In some patients, B-cell repopulation leads to a relapse of the disease. However, further investigations to be able to clarify clear patterns predictive of relapse are still needed.

\section{BACKGROUND}

Rituximab is licensed and well established for patients with non-Hodgkin's lymphoma. Rituximab has also been approved by the US Food and Drug Administration and by the European Medicines Agency in Europe for the treatment of patients with RA who have had an inadequate response or were intolerant to tumour necrosis factor (TNF) inhibitors. In these patients, according to the licence, rituximab is given intravenously as two $1 \mathrm{~g}$ infusions (with intravenous glucocorticoid premedication; table 2), separated by 2 weeks, with concomitant methotrexate. $^{2}{ }^{3}$ Worldwide, more than 100000 patients have received rituximab to date for RA. ${ }^{20} 21$

In earlier studies, rituximab has shown efficacy when used alone (category Ib) and in combination with other agents, including methotrexate ${ }^{1}$ (category Ia). The efficacy and durability of monotherapy is less than that of combination treatment with methotrexate (category Ib). Subsequent studies on rituximab in combination with methotrexate have proved to be successful in markedly reducing inflammatory activity and increasing functional ability and quality of life $^{3}$ (category Ia). In responding

Table 1 Evidence hierarchy

\begin{tabular}{ll}
\hline $\begin{array}{l}\text { Category of } \\
\text { evidence }\end{array}$ & Type of study \\
\hline la & Meta-analyses of RCT or RCT $\geq 1$ result \\
$\mathrm{lb}$ & RCT \\
$\mathrm{Ila}$ & Controlled study without randomisation \\
$\mathrm{Ilb}$ & Quasi-experimental study \\
$\mathrm{III}$ & $\begin{array}{l}\text { Non-experimental descriptive studies such as comparative, correlation } \\
\text { and case-control studies }\end{array}$ \\
IV & $\begin{array}{l}\text { Expert committee reports or opinion or clinical experience of respective } \\
\text { authorities, or both }\end{array}$ \\
\hline
\end{tabular}

Modified from Shekelle et al. ${ }^{5}$

RCT, randomised controlled trial. patients, the duration of the response to a single course of rituximab usually lasts more than 6 months $^{22}$ (category Ib). Recent phase III studies have also expanded information on the efficacy of rituximab in methotrexate inadequate responders ('MIRROR' and 'SERENE' studies) ${ }^{23} 24$ and addressed methotrexate-naive patients ('IMAGE' study). ${ }^{25}$ Response rates in the former studies demonstrated the superiority of rituximab over placebo. In the IMAGE study involving methotrexate-naive patients, rituximab plus methotrexate was superior in clinical and functional outcomes to methotrexate alone; there was also a significant reduction in radiographic progression versus methotrexate monotherapy after 6, 12 and 24 months. ${ }^{25}$ Inhibition of structural damage progression had already been shown previously in patients with previous inadequate response to TNF inhibitors treated with methotrexate and rituximab, and this effect was sustained after 2 years (category Ib). ${ }^{26} 27$

The wider use of rituximab has meant a better appreciation of the associated safety issues with, in particular, focus on infection risk. The oncology literature has highlighted concerns over hepatitis B reactivation. ${ }^{28} 29$ In addition, more specific consequences of B-cell depletion, namely low baseline IgG levels and the observation of subsequent greater infection risk has indicated the value of checking IgG levels before administering rituximab. ${ }^{30}$

In addition to data from clinical trials on the efficacy and safety of rituximab, drug registries may provide information that is complementary to information from the trials. Registries include patients with severe comorbidities that contraindicate the use of, for example, TNF inhibitors, as well as patients treated with rituximab without the previous use of other biological agents and/or receiving rituximab as monotherapy. ${ }^{31} 32$

\section{RECOMMENDATIONS \\ Indication}

At present, in line with the current licensed indication, rituximab may be used in adult patients with RA who qualify for treatment with biological agents and have had an inadequate response or intolerance to one or more TNF inhibitors ${ }^{33}$; patients with a contraindication to TNF inhibitors have not yet been adequately studied. However, registry and non-interventional studies have reported $17-20.5 \%$ of patients receiving rituximab as their first biological disease-modifying antirheumatic drug (DMARD). ${ }^{30} 34$ Before concluding that a patient has not responded to a TNF inhibitor, attempts should be made to improve the ongoing regimen by optimising the DMARD or TNF inhibitor treatment, ${ }^{35}$ considering respective recommendations. The SERENE and MIRROR studies (described later) confirm efficacy in a methotrexate-inadequate responder/TNF inhibitor-naive population and the IMAGE study in methotrexate-naive patients. ${ }^{23-25}$

Table 2 Doses of rituximab and glucocorticoids in six randomised controlled clinical trials

\begin{tabular}{|c|c|c|c|}
\hline Study & Rituximab dose & Intravenous glucocorticoid & Oral glucocorticoid \\
\hline Edwards et al ${ }^{1}$ (MTX-IR) & $2 \times 1000 \mathrm{mg}$ & $2 \times 100 \mathrm{mg} \mathrm{MP}$ on days 1 and 15 & $60 \mathrm{mg} P$ days $2,4-7+30 \mathrm{mg} P$ days $8-14$ \\
\hline \multirow[t]{3}{*}{ Emery et a ${ }^{2}$ (DANCER) (MTX \pm TNF-IR) } & $2 \times 1000 \mathrm{mg}$ or $2 \times 500 \mathrm{mg}$ & (1) 0 & (1) 0 \\
\hline & & (2) $2 \times 100 \mathrm{mg} \mathrm{MP}$ & (2) 0 \\
\hline & & (3) $2 \times 100 \mathrm{mg} \mathrm{MP}$ & (3) $60 \mathrm{mg} P$ days $2-7+30 \mathrm{mg} \mathrm{P}$ days $8-14$ \\
\hline Cohen et $a{ }^{3}$ (REFLEX) (TNF-IR) & $2 \times 1000 \mathrm{mg}$ & $2 \times 100 \mathrm{mg} \mathrm{MP}$ & $60 \mathrm{mg} P$ days $2-7+30 \mathrm{mg} P$ days $8-14$ \\
\hline Tak et all (IMAGE) (MTX-naive) & $2 \times 1000 \mathrm{mg}$ or $2 \times 500 \mathrm{mg}$ & $2 \times 100 \mathrm{mg} \mathrm{MP}$ & \\
\hline Rubbert-Roth et al ${ }^{23}$ (MIRROR) (MTX-IR) & $2 \times 1000 \mathrm{mg}$ or $2 \times 500 \mathrm{mg}$ or $1 \times 1000 \mathrm{mg}$ and $1 \times 500 \mathrm{mg}$ & $2 \times 100 \mathrm{mg} \mathrm{MP}$ & \\
\hline Emery et al ${ }^{24}$ (SERENE) (MTX-IR) & $2 \times 1000 \mathrm{mg}$ or $2 \times 500 \mathrm{mg}$ & $2 \times 100 \mathrm{mg} \mathrm{MP}$ & \\
\hline
\end{tabular}

No marked difference in efficacy between the two rituximab doses. ${ }^{2}{ }^{31-33}$ IMAGE: $2 \times 1000 \mathrm{mg}$ associated with structural retardation first 24 weeks; maintenance with both rituximab doses week 24 to 2 years. Premedication associated with reduced infusion-related events infusion one; minimal difference for infusion two.

IR, inadequate-responder; MP, methylprednisolone; MTX, methotrexate; P, prednisolone; TNF, tumour necrosis factor. 
Table 3 Pooled analysis ${ }^{38}$ of response rates for autoantibody positive and negative patients from the MIRROR ${ }^{23}$ and SERENE ${ }^{24}$ studies

\begin{tabular}{lcclll}
\hline & Week 24 & & & Week 48 & \\
\cline { 2 - 3 } \cline { 5 - 6 } & Seropositive & Seronegative & & Seropositive & Seronegative \\
\hline ACR responses $(\mathrm{n})$ & 514 & 106 & & 506 & 101 \\
ACR20 $(\%)$ & $62.3^{*}$ & 50.9 & & $71.1^{*}$ & 51.5 \\
ACR50 $(\%)$ & $32.7^{*}$ & 19.8 & & $44.9^{* *}$ & 22.8 \\
ACR70 $(\%)$ & 12.1 & 5.7 & & $20.9^{*}$ & 6.9 \\
EULAR outcomes $(\mathrm{n})$ & 507 & 105 & & 496 & 101 \\
EULAR response (\%) & $74.8^{*}$ & 62.9 & & $84.3^{*}$ & 72.3 \\
Mean change DAS28 & $-1.97^{* *}$ & -1.50 & & $-2.48^{* * *}$ & -1.72 \\
DAS28 categories (n) & 510 & 105 & & 499 & 101 \\
Low disease (\%) & 16.9 & 10.5 & & $26.5^{*}$ & 12.9 \\
DAS28 remission (\%) & 10.6 & 4.8 & & 13.2 & 5.9 \\
\hline
\end{tabular}

${ }^{*} p<0.05,{ }^{* *} p<0.001,{ }^{* * *} p<0.0001$ vs seronegative.

ACR, American College of Rheumatology; DAS28, disease activity score 28; EULAR, European League Against Rheumatism.

Current evidence on the efficacy of rituximab relates primarily to rheumatoid factor (RF) positive patients ${ }^{12}$ (category Ia). While in the phase III (REFLEX) study on TNF inhibitor nonresponders, a response was seen in RF-negative patients, ${ }^{3}$ other substudy analyses on RF-negative patients showed that the response in this population was not significantly different from placebo-treated patients. ${ }^{2} 36$ Indeed, in the first of these studies (REFLEX), protection from joint damage was only evident in seropositive patients. ${ }^{37}$

Recently, pooled data from two phase III studies in methotrexate-inadequate responder populations as well as a substudy from the IMAGE study that evaluated methotrexate-naive patients have all reinforced the view that seropositive patients (anti-citrullinated peptide antibody (ACPA), RF or both) demonstrate a more robust response to rituximab ${ }^{25} 38$ (table 3; data discussed in the supplementary material available online only). In the IMAGE study, ${ }^{25}$ there was evidence of significantly greater joint protection in the seropositive subpopulation treated with rituximab and methotrexate; while in the seronegative group, inhibition of progression of damage in each treatment group was comparable and generally low even in the placebo/methotrexate group. Superior efficacy has also been demonstrated in drug registries for patients who were RF and/or ACPA positive ${ }^{39-42}$ when compared with the seronegative patient group. Another study (discussed further in the supplementary material available online only) identified the four best potential biomarkers from the REFLEX study (that included IgA RF and IgG anti-CCP3) and applied these, together with IgM and IgG isotypes of RF to the SERENE study; the presence of any RF isotype or IgG ACPA was associated with a higher American College of Rheumatology (ACR50) response. ${ }^{43}$ A multivariate analysis from a single-centre study suggested $R F$ (and not ACPA), low disability and the previous number of TNF inhibitors as predictive of response to rituximab. ${ }^{44}$ Therefore, while one randomised trial suggested efficacy for rituximab in seronegative patients, data from the other trials described above, together with descriptions of a more unpredictable safety profile in these patients, ${ }^{45}$ suggest it would perhaps be more appropriate for alternative treatment approaches to be considered.

\section{Considerations for initiating treatment}

Before treatment, an individual therapeutic goal should be established as a shared decision between each patient and the treating physician. The doctor should be experienced in the diagnosis and treatment of RA, including the use of biological DMARD agents. The general principles should follow published recommendations. ${ }^{46}{ }^{47}$ Patients considered for treatment generally should thus have active disease in line with inclusion in clinical trials, defined as at least moderate disease activity by composite scores, such as by the 28-joint disease activity score (DAS28, $>3.2$ ), the simplified disease activity index (SDAI, >11), the clinical disease activity index (CDAI, $>10)$ or similar measures. ${ }^{48} 49$

So far, in the phase II and phase III studies of TNF inhibitor failure patients, rituximab was started as soon as 4 weeks after the last dose of etanercept and 8 weeks after the last dose of infliximab or adalimumab. Exclusion criteria comprised evidence of major systemic involvement due to RA, other major illnesses or laboratory abnormalities, and a history of recurrent relevant infections. $^{23}$

Patients treated in real life are more heterogeneous than in RCT with regard to comorbidities, disease activity as well as previous and concomitant use of other medications; information from drug registries, therefore, provides additional important insights. ${ }^{34} 5051$

\section{Screening before initiating rituximab}

Initiation of rituximab should be preceded by recording a detailed history (regarding chronic or recent comorbidity, such as cardiovascular and pulmonary diseases, recurrent infections and allergies) and a complete physical examination to consider possible contraindications in all patients, especially the older patient. Special attention should be paid to vaccinations. Patients should be well informed of the full therapeutic profile of rituximab, including all risks and benefits.

In clinical trials on rituximab, patients with RA have been prescreened for hepatitis $B$ and $C$; patients testing negative for hepatitis B virus (HBV), hepatitis B surface antigen (HBsAg), but positive for antibodies against hepatitis $B$ core $(\mathrm{HBc})$ antigen were allowed rituximab therapy if negative for HBV DNA. While cases of $\mathrm{HBV}$ reactivation are widely described in the oncology literature, only one case report of $\mathrm{HBV}$ reactivation in a patient with RA treated with rituximab ${ }^{52}$ has been reported. Data from patients with RA as well as from the oncology and hepatology literature are discussed in the supplementary material, available online only. The risk of hepatitis $C$ virus is in contrast, unclear with conflicting data and perspectives on the possible consequences of rituximab and chemotherapy generally. ${ }^{53} 54$

As always, the individual risk-benefit ratio should be evaluated and discussed with the patient. Management of such patients should be in consultation with an expert gastroenterologist/ hepatologist. Expert advice is that serological markers of HBV infection should be obtained before starting treatment. As discussed in the supplementary material (available online only), reactivation has been documented in $\mathrm{HBsAg-negative} \mathrm{as} \mathrm{well} \mathrm{as}$ HBsAg-positive patients, ${ }^{28}{ }^{29}$ stressing the importance of measuring not only $\mathrm{HBsAg}$ but also antibodies against $\mathrm{HBc}$ antigen to identify positive carrier status. $\mathrm{HBsAg}$ negativity (with also anti-HBs antibody negativity) identifies those requiring vaccination before immunosuppressive therapy. HBV DNA titres are not indicated for screening, rather assessment of viral load and response in established chronic HBV infection. Several recommendations have been published including those by the Centers for Disease Control and Prevention, although they partly differ ${ }^{55-57}$ Nevertheless, patients who are HBsAg positive and/or anti-HBc positive should be treated prophylactically. The management of occult HBV infection with anti-HBc positivity alone remains unclear; in such patients HBV DNA could be determined and then prophylactic therapy considered; if not undertaken, close follow-up to detect a rise in HBV DNA is recommended. Routine testing for hepatitis $C$ should also be considered. A recent review paper and editorial advise a similar 
approach with a call for revision of ACR guidelines with, in addition, a recent publication of a provisional clinical opinion from the American Society of Clinical Oncology. ${ }^{58-60}$

Chest radiography was also carried out in the clinical trials. Patients who did not respond to TNF inhibitor treatment will also have been prescreened for the presence of active or latent tuberculosis. In the RA clinical trials on rituximab before TNF inhibitor, patients with active tuberculosis were excluded, but patients were not screened for latent tuberculosis by any testing. The fact that rituximab is administered in RA with two pulses of glucocorticoid may by itself contribute to the risk of reactivation of tuberculosis. ${ }^{61}$ However, there is no evidence of an increased frequency of tuberculosis in patients with lymphoma treated with rituximab ${ }^{62}$ and, therefore, at this time there is no evidence indicating the necessity to screen patients systematically for tuberculosis before using rituximab in those with RA.

Apart from routine laboratory tests usually performed in patients with RA before initiating new treatments, baseline Ig levels should be determined, as a reduced baseline level of $\operatorname{Ig} G$ is a risk factor for severe infections with rituximab; ${ }^{30}$ in addition, decreased levels of IgM and IgA have been observed with rituximab over time ${ }^{18}$ (category Ia). Monitoring the IgG level at baseline before each rituximab cycle and longitudinally is therefore advised, with patients particularly at risk, such as those showing reduced IgG levels at baseline or indeed other higher risk groups such as older people, requiring particularly close monitoring of levels and vigilance for infections. On all these grounds, rituximab treatment in RA patients with hypogammaglobulinaemia (below the lower limit of normal) should be considered with caution (see also section on 'Immunoglobulins and infection risk').

In clinical trials, B-cell levels have been measured, but the utility of these measurements in routine practice is not confirmed.

\section{Vaccination}

Some data from the oncology literature indicate that in patients receiving rituximab, response to vaccination may be ineffective. ${ }^{62}$ Patients with RA receiving rituximab have been investigated for their response to vaccination in two studies, one of which was a RCT63 64 (discussed in the supplementary material, available online only). Any patient considered for rituximab therapy should receive all indicated vaccines (hepatitis B for at-risk population, pneumococcus, tetanus toxoid every 10 years, influenza annually) before treatment. Ideally, vaccination should be undertaken at least 4 weeks before rituximab therapy. More data are needed on the potential risk of vaccination with live vaccines, which are therefore not recommended for rituximab-treated patients. European League Against Rheumatism (EULAR) recommendations on vaccination provide additional guidance for patients with rheumatological diseases treated with biological agents. ${ }^{65}$

\section{Treatment dose and co-medication}

\section{Treatment dosage}

In patients who have received previous TNF inhibitor treatment, rituximab use is licensed at a dose of $1000 \mathrm{mg}$ per infusion on days 1 and $15 .{ }^{3}$ Rituximab showed significant efficacy

Table 4 Summary of response rates in the six key randomised controlled studies evaluating rituximab and methotrexate

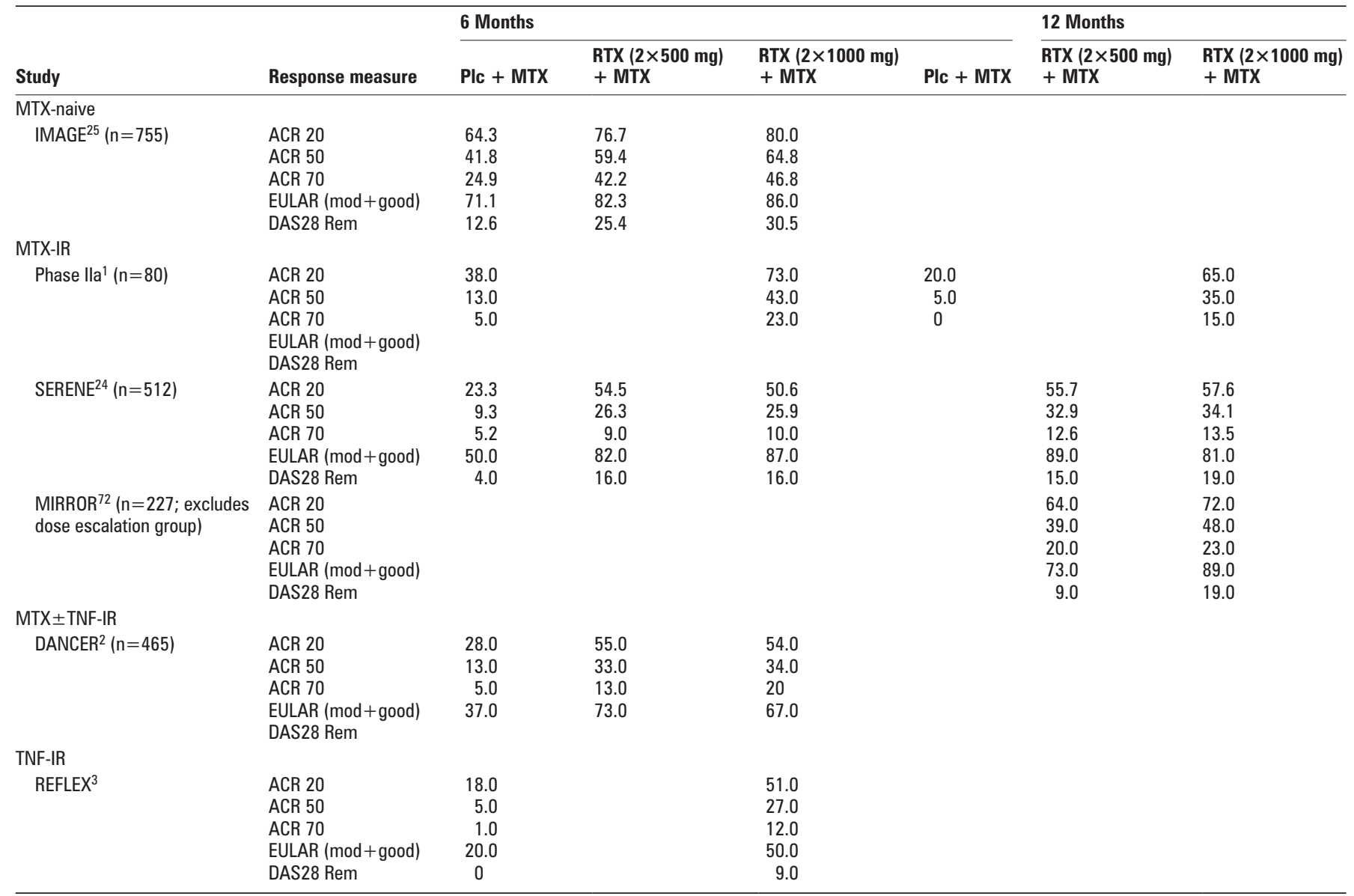

ACR, American College of Rheumatology; DAS28, disease activity score 28; EULAR, European League Against Rheumatism; IR, inadequate-responder; mod, moderate; MTX, methotrexate; Plc, placebo; Rem, remission; RTX, rituximab; TNF, tumour necrosis factor. 
on signs and symptoms as well as physical function in this population. The effect on structural damage was also evaluated in that trial (REFLEX), in which the $2 \times 1000 \mathrm{mg}$ dose was studied. Radiographic benefit compared with placebo was demonstrated at 1 year ${ }^{26}$ (but not at 24 weeks), ${ }^{3}{ }^{26}$ with recent data confirming maintenance of retardation at 2 years. ${ }^{27}$

Subsequent studies in all other RA populations, namely patients with previous inadequate response to traditional DMARD including methotrexate and patients naive to methotrexate, have also evaluated a lower dose of $500 \mathrm{mg}$ per infusion. ${ }^{2} 23-25$

The SERENE ${ }^{24}$ and MIRROR ${ }^{23}$ studies both addressed methotrexate-inadequate responder patients and included two courses of $2 \times 500$ and $2 \times 1000 \mathrm{mg} 6$ months apart; SERENE also had a placebo arm for comparison, while MIRROR adopted an additional dose escalation regimen-one course of $2 \times 500 \mathrm{mg}$ followed by a course of $2 \times 1000 \mathrm{mg}$. ACR20, ACR50 and ACR70 response rates in patients treated with these rituximab doses were similar (as detailed in table 4 and discussed further in the supplementary material, available online only) (category Ib). Effects on joint damage were not assessed in this study.

In the IMAGE study in methotrexate-naive patients, the $2 \times 500$ and $2 \times 1000 \mathrm{mg}$ dose groups were again compared. ${ }^{25}$ The clinical and functional outcomes were very similar. The higher dose $(2 \times 1000 \mathrm{mg})$ cohort demonstrated significantly superior joint protection compared with placebo, while the lower dose $(2 \times 500$ $\mathrm{mg}$ ) had numerical, although not statistical, radiographic benefit during the first 24 weeks. Beyond this time point, however, (study duration of 2 years) radiographic progression was minimal and indeed similar in both dose groups. These results are illustrated in the supplementary section available online only.

These data are important in expanding upon those observed in the previoius TNF inhibitor-experienced population from the REFLEX study described above. The optimal dose of rituximab thus remains insufficiently defined, with considerable data suggesting an overall equivalence of $2 \times 500 \mathrm{mg}$ with the licensed dose of $2 \times 1000 \mathrm{mg}$ for clinical efficacy outcomes and medium-term maintenance of radiographic non-progression. More research is required in this area.

In the phase II trial, the ACR responses of patients treated with rituximab in combination with methotrexate were numerically superior to those receiving rituximab monotherapy (table ). ${ }^{2}$ Rituximab monotherapy was also shown to be more effective than placebo only in ACR20 response but not in ACR50 and ACR70 responses ${ }^{2}$ (category Ib). Rituximab is therefore only licensed in combination with methotrexate (www. accessdata.fda.gov/scripts/cder/drugsatfda, www.ema.eu.int/ humans/Humans/EPAR/mabthera/mabthera). In clinical practice this will usually be a dose of 10-25 mg methotrexate per week, unless intolerance precludes such doses (category Ib).

\section{Other combinations}

A number of abstracts (small observational studies and registry data) have described the use of rituximab with DMARD other than methotrexate ${ }^{31} 66$ (category III). They consistently demonstrate that leflunomide can be used safely and effectively as background DMARD therapy. The observational study, SUNDIAL, demonstrated the safety of rituximab on a variety of background non-biological DMARD and combinations ${ }^{66}$ (category III). An initial, relatively small randomised study (TAME) assessed rituximab on background etanercept or adalimumab and showed more infections with this combination ${ }^{67}$ (category IIa); this approach should therefore be avoided. Data are available from the phase II trials on cyclophosphamide as co-medication, ${ }^{1}$ although given the availability of safer and more effective alternatives, in patients with RA at least, this expert group felt that cyclophosphamide is unnecessary as a co-medication.

\section{Rituximab administration and glucocorticoid premedication}

To reduce the frequency and severity of infusion reactions, patients should receive $100 \mathrm{mg}$ methylprednisolone intravenously before rituximab infusions (category Ib). This is particularly indicated before the first infusion and can also be given before the second infusion of each cycle, although the indication may not be as strong for the latter. ${ }^{2} 68$ Paracetamol and antihistamines may be required, and although they have been used for premedication in all clinical trials on RA, there is no clear evidence from these that antihistamines should be used systematically.

\section{Evaluation and management of response/non-response} Response assessment

Routine rheumatological assessments should be performed at baseline and periodically according to standards of care for therapies with biological agents and methotrexate. Response to rituximab should be assessed by validated composite measures of disease activity (eg, the DAS28, SDAI or CDAI); ${ }^{48}$ functional assessment (health assessment questionnaire), and evaluation of radiographic progression further complement the use of these scores. At least a low disease activity range (DAS28 $\leq 3.2$, SDAI $<11$ or CDAI $<10$ ) and a maximisation of functional ability and quality of life should be the target to aim for with regard to a desirable disease state. ${ }^{49}$

\section{Response profile}

Rituximab has a more distinctive response profile in that the onset of action of rituximab is slower than that of the other biological DMARD. Furthermore, it should be noted that intravenous glucocorticoid premedication will produce an early, albeit a usually transient, response before 8 weeks. It is important that this is communicated to the patient. A patient should be regarded as a responder if the response criteria are met after an observation period of at least 16 weeks from the initiation of treatment according to the recommended dosing schedule. Indeed, in most patients, a response (ie, some degree of improvement in disease activity) is usually seen by 16 weeks after the first infusion ${ }^{1-3}$ (category Ia). Rituximab usually leads to rapid B-cell depletion ${ }^{1-3}$ (category Ia).

\section{Considerations for repeated treatment}

Repeated treatment should be considered after at least 24 weeks (category IV). In line with the 'treat-to-target' and EULAR RA management recommendations, ${ }^{46} 47$ this should be considered in patients who do not reach remission (exhibiting a DAS28 $\geq 2.6$, SDAI $>3.3$ or $\mathrm{CDAI}>2.8)^{49}$ or at least low disease activity (although with consideration of alternative targets if individual factors make it unlikely that either of these are achieveable). ${ }^{46}$ It is worth noting that the earliest retreatment was undertaken after 4 months. ${ }^{3}$

Notwithstanding the above, the optimal treatment paradigm for rituximab has not been definitively determined. Options include treatment on flare as practised in earlier RCT, regular re-treatment, for example, every 6 months, treatment with any deterioration or treatment-to-target. This is discussed in more detail in the supplementary material, available online only, with data from pooled phase II and III studies ${ }^{69}$ as well as preliminary data from the German registry. ${ }^{70}$ Retrospective data support in principle a treatment-to-target strategy, whereas regular re-treatment may risk overtreatment in some patients. Of note, a lack 
of long-term safety data relating to different dosing regimens in the re-treatment of RA means it is important that caution is exercised if or when patients are being regularly re-treated.

\section{Managing non-response}

Several studies have reported the outcome of re-treating rituximab non-responders with a further cycle. Several of these (with, in one study, $95 \%$ of non-responders showing poor early peripheral blood B-cell depletion using a high sensitivity assay) ${ }^{71}$ demonstrate that seropositive patients who fail to respond to a first course of rituximab may respond to a second course 232436667071 (accompanied by more complete B-cell depletion). ${ }^{71}$ A couple of other studies, however, suggest little improvement to be gained with re-treatment. ${ }^{36} 72$ In light of the availability of other therapeutic options, for individual (particularly seronegative) patients who are rituximab non-responders or insufficient responders, other treatment options should be considered depending on previous drug history.

\section{Post-TNF inhibitor failure and biological DMARD therapy after rituximab}

Post-TNF inhibitor failure

A few observational, registry-based and single-centre studies have compared the use of rituximab in TNF inhibitor inadequate responders versus switching to another TNF inhibitor ${ }^{73-77}$ (discussed in the supplementary material, available online only). There has been no head-to-head comparison to date, with a recent meta-analysis confirming similar clinical benefits from these RCT; 78 associated management recommendations did not establish a preference for a particular biological agent in this situation. ${ }^{47}$

\section{Safety of other biological DMARD post-rituximab}

Switching from rituximab to a TNF inhibitor has been associated with a numerically, but not statistically, significant increase in serious infections in an early study; ${ }^{79}$ a subsequent report providing further follow-up of the same cohort did not suggest a major increase in infections under these circumstances. ${ }^{80}$ In this latter report TNF inhibitors were usually initiated at least 4 months after rituximab (when insufficient treatment response would be judged). No significant increase in serious infections was noted compared with the incidence before the new biological DMARD (TNF inhibitors in the majority of cases), with similar rates to a biological DMARD-naive group commenced on a TNF inhibitor; however, a wide interval from rituximab exposure to subsequent biological DMARD exposure was present (0.5-37 months) with a small sample size. ${ }^{80}$ Data from the French Autoimmunity and Rituximab and Orencia in Rheumatoid Arthritis registries indicate that previous use of rituximab followed by treatment with abatacept does not increase the short-term risk of severe infection. ${ }^{81}$ These are preliminary reports and clearly further data on the safety of using other biological DMARD before or after rituximab need to be established.

\section{Cost-effectiveness}

Rituximab has been evaluated as a cost-effective treatment ${ }^{82}$ with three studies comparing rituximab with TNF inhibitor ${ }^{83-85}$ following TNF inhibitor failure; the methods differed slightly but all suggested equivalent/favourable results towards rituximab.

\section{Role of rituximab in other autoimmune diseases}

In addition to RA, accumulating evidence suggests rituximab could also be an effective treatment option in the management of patients with vasculitis, connective tissue diseases and other autoimmune conditions. Data that have emerged from recent RCT are summarised in the supplementary material available online only.

\section{CONTRAINDICATIONS AND AE Contraindications}

Contraindications to rituximab include hypersensitivity to rituximab or other murine proteins, active severe infections and severe heart failure (New York Heart Association class IV; www.accessdata.fda.gov/scripts/cder/drugsatfda, www.ema. eu.int/humans/Humans/EPAR/mabthera/mabthera). ${ }^{33}$ In nonHodgkin's lymphoma, contraindications have been restricted to hypersensitivity to components of this product or murine proteins. Patients with active infections (acute or chronic) should not be treated with rituximab.

\section{Use in children}

Safety and efficacy in children with rheumatic diseases has not been established although an increasing number of case reports and series of successful rituximab usage are available in the literature. ${ }^{86-92}$

\section{Pregnancy}

Rituximab treatment during pregnancy is contraindicated. A recent review ${ }^{93}$ of pregnancy outcomes from the rituximab global drug safety database identified 231 cases of pregnancy associated with maternal rituximab exposure. Of 153 pregnancies with known outcomes, 90 resulted in live births, 33 ended in spontaneous abortion, with one stillbirth at 20 weeks' gestation (umbilical knot) and 28 elective terminations. Twenty-two of the live births were premature, with one neonatal death at 6 weeks. Eleven infants had haematological abnormalities at birth; four neonatal infections and two congenital malformations were reported. A recent review of RA medications in pregnancy included B-cell levels during eight of these cases of rituximab exposure during pregnancy, ${ }^{94}$ two cases were during the first trimester and were not associated with any B-cell depletion in the fetus; six cases in the second or third trimesters included three with similar rituximab levels to the mother with markedly reduced/undetectable B-cell numbers-spontaneous recovery was, however, observed within 6 months. IgG levels were tested and were normal in four out of the six cases and vaccination responses remained intact. The appropriate time interval between the last rituximab treatment and subsequent conception remains unclear. Although additional data are now becoming available, further data are required before safety recommendations for pregnancy can be produced; until that time contraception is recommended for 12 months after the last rituximab application in the label, and rituximab should also be avoided in lactating women (www.accessdata.fda.gov/scripts/ cder/drugsatfda, www.ema.eu.int/humans/Humans/EPAR mabthera/mabthera). ${ }^{33}$

\section{Adverse events}

Table 5 lists the more frequent $(\geq 2 \%)$ AE recorded during the 6-month placebo-controlled period from nine studies (IIa, IIb (DANCER), DANCER extension, REFLEX (and REFLEX extension), SERENE, MIRROR, SUNRISE and SIERRA studies); ${ }^{18}$ data for the placebo and methotrexate group have been pooled from the phase IIa, IIb (DANCER), REFLEX and SERENE studies.

\section{Infusion-related reactions}

The tolerability and safety of rituximab has been well described in clinical trials on patients with RA and review articles on 
non-Hodgkin's lymphoma ${ }^{62}$ (category III) ${ }^{1}{ }^{18}$ (category Ia). The most frequent $\mathrm{AE}$ are infusion reactions (30-35\% with the first infusion with concomitant glucocorticoids). Fewer reactions are observed with the second and subsequent infusions ${ }^{1-3}$ 18 (category Ia). They are usually mild to moderate, but may require therapeutic intervention (additional paracetamol,

Table 5 AE occurring during the 6-month placebo-controlled period of nine studies ${ }^{18}$

\begin{tabular}{lll}
\hline & $\begin{array}{l}\text { Placebo+MTX } \\
(\mathbf{n = 5 7 0 )}\end{array}$ & $\begin{array}{l}\text { Rituximab+MTX } \\
(\mathbf{n}=\mathbf{8 7 7 )}\end{array}$ \\
\hline Total patients (\%) with $\geq 1 \mathrm{AE}$ infection & $223(39.1)$ & $353(40.3)$ \\
$\quad$ Infections occurring in $\geq 2 \%$ of patients & & \\
Nasopharyngitis & $43(7.5)$ & $63(7.2)$ \\
Upper respiratory tract infections* & $37(6.5)$ & $64(7.3)$ \\
Urinary tract infection* & $31(5.4)$ & $31(3.5)$ \\
Bronchitis* & $19(3.3)$ & $27(3.1)$ \\
Sinusitis & $20(3.5)$ & $25(2.9)$ \\
Gastroenteritis & $14(2.5)$ & $12(1.4)$ \\
Pharyngitis & $12(2.1)$ & $11(1.3)$ \\
Total patients (\%) with a serious infection & $9(1.6)$ & $15(1.7)$ \\
Pneumonia & $2(0.4)$ & $2(0.2)$ \\
Gastroenteritis & $2(0.4)$ & $1(0.1)$ \\
Pyelonephritis & 0 & $3(0.3)$ \\
Respiratory tract infection & $2(0.4)$ & 0 \\
Abscess bacterial & $1(0.2)$ & 0 \\
Abscess intestinal & $1(0.2)$ & 0 \\
Bronchitis & 0 & $1(0.1)$ \\
Bronchopneumonia & $1(0.2)$ & 0 \\
Cellulitis & 0 & $1(0.1)$ \\
Cellulitis gangrenous & 0 & $1(0.1)$ \\
\hline
\end{tabular}

Infusion-related reactions were the most common adverse event (AE) (25\% infusion 1). Data for the placebo + methotrexate (MTX) group pooled from trials lla, DANCER, REFLEX and SERENE. The overall rate $(95 \% \mathrm{Cl})$ of AE was 359.6 events per 100 patientyears (354.4 to 364.9 ) with highest rates during course 1 ; for serious $A E$, the rate $(95 \%$ Cl) was 17.85 events per 100 patient-years (16.72 to 19.06).

${ }^{*}$ Occurred in $\geq 10 \%$ patients. antihistamines, bronchodilators, eventually glucocorticoids). Severe infusion reactions leading to drug discontinuation are uncommon $(<1 \%)$ and are mainly restricted to the first infusion (Roche data on file). Their frequency is reduced by the use of concomitant intravenous steroids ${ }^{1-3}$ (category la; www. accessdata.fda.gov/scripts/cder/drugsatfda, www.ema.eu.int/ humans/Humans/EPAR/mabthera/mabthera). ${ }^{33}$ There have been several reports from haematology experience on the safety of shortened (60-90 $\mathrm{min}$ ) infusion times..$^{95-99}$

In the context of glucocorticoid use with rituximab, $\mathrm{AE}$ due to glucocorticoids also need to be considered.

\section{Serious infections}

Rituximab does not seem to increase the risk of infections in patients with HIV with lymphoma ${ }^{62} 100$ (category IIb). In the oncology literature, rituximab does not markedly add to the risk of infections induced by chemotherapy; this includes opportunistic infections ${ }^{62}$ and also herpes zoster infections, although there was one case of disseminated and fatal herpes zoster infection. ${ }^{62}{ }^{101}$ In the long-term safety analysis of RA trials $^{18}$ herpes zoster occurred in $2 \%$ of patients $(n=49 ; 0.98$ events/100 patient-years) with only one case a serious $\mathrm{AE}$; this rate appears to be similar to the rate seen with TNF inhibitors (1.11 events/100 patient-years). ${ }^{102}$

In two clinical trials carried out on patients with $\mathrm{RA}^{2}{ }^{3}$ a numerically higher rate of serious infections (but not opportunistic infections, including tuberculosis) was seen in patients receiving rituximab at $2 \times 1000 \mathrm{mg}$ compared with those receiving placebo: 4.7 versus 3.2/100 patient-years in the DANCER study and 5.2 versus 3.7/100 patient-years in the REFLEX study ${ }^{3}$ (category III). In the recent IMAGE study in methotrexate-naive patients, however, serious infections were lower in the two rituximab dosage groups (1000 and $500 \mathrm{mg}$ ) compared with placebo $(3.74,4.61$ and 6.09 events/100 patientyears, respectively). ${ }^{25} \mathrm{~A}$ recent meta-analysis included three

Table 6 Summary of additional clinical and research aspects for future consideration

\begin{tabular}{|c|c|}
\hline \multicolumn{2}{|c|}{ Future clinical and research agenda } \\
\hline \multirow[t]{9}{*}{ Safety } & Rituximab in the context of concomitant \\
\hline & Milder congestive heart failure (NYHA I-III) \\
\hline & Demyelinating disorders (efficacy seen in phase I-II studies of MS/NMO) \\
\hline & New-onset malignancy \\
\hline & Registry data \\
\hline & tuberculosis reactivation \\
\hline & Rare serious $A E(P M L)$ \\
\hline & Parameters associated with infection risk (lg) \\
\hline & Vaccination-minimal interval between vaccine and RTX administration \\
\hline \multicolumn{2}{|r|}{ - } \\
\hline \multirow[t]{2}{*}{ Disease groups } & Connective tissue disorders \\
\hline & RA/vasculitis; overlap syndromes \\
\hline \multirow[t]{3}{*}{ Dosage regimen } & Dose, dosage schedule \\
\hline & Different induction and maintenance regimens? \\
\hline & Impact of different dosage regimens on structural progression \\
\hline \multirow[t]{3}{*}{ Concomitant medication } & Alternative DMARD to MTX \\
\hline & Timing and initiation of DMARD \\
\hline & Combination RTX with other biological agent \\
\hline \multirow[t]{2}{*}{ Flare and retreatment } & Early signs of flare/reactivation \\
\hline & Long-term impact of re-treatment/repeat multiple cycles \\
\hline \multirow[t]{3}{*}{ Translational research } & Mechanism of action of RTX \\
\hline & Biomarkers of response \\
\hline & Indicators of re-treatment (B cell/subsets) \\
\hline Switching biological therapies & Merit of RTX following initial TNF-i failure compared to alternative TNF-i or other biological agent \\
\hline Pharmacoeconomic analyses & \\
\hline
\end{tabular}

TNF-i, tumour necrosis factor inhibitor. 


\section{Box 1 Points to consider for treatment with rituximab}

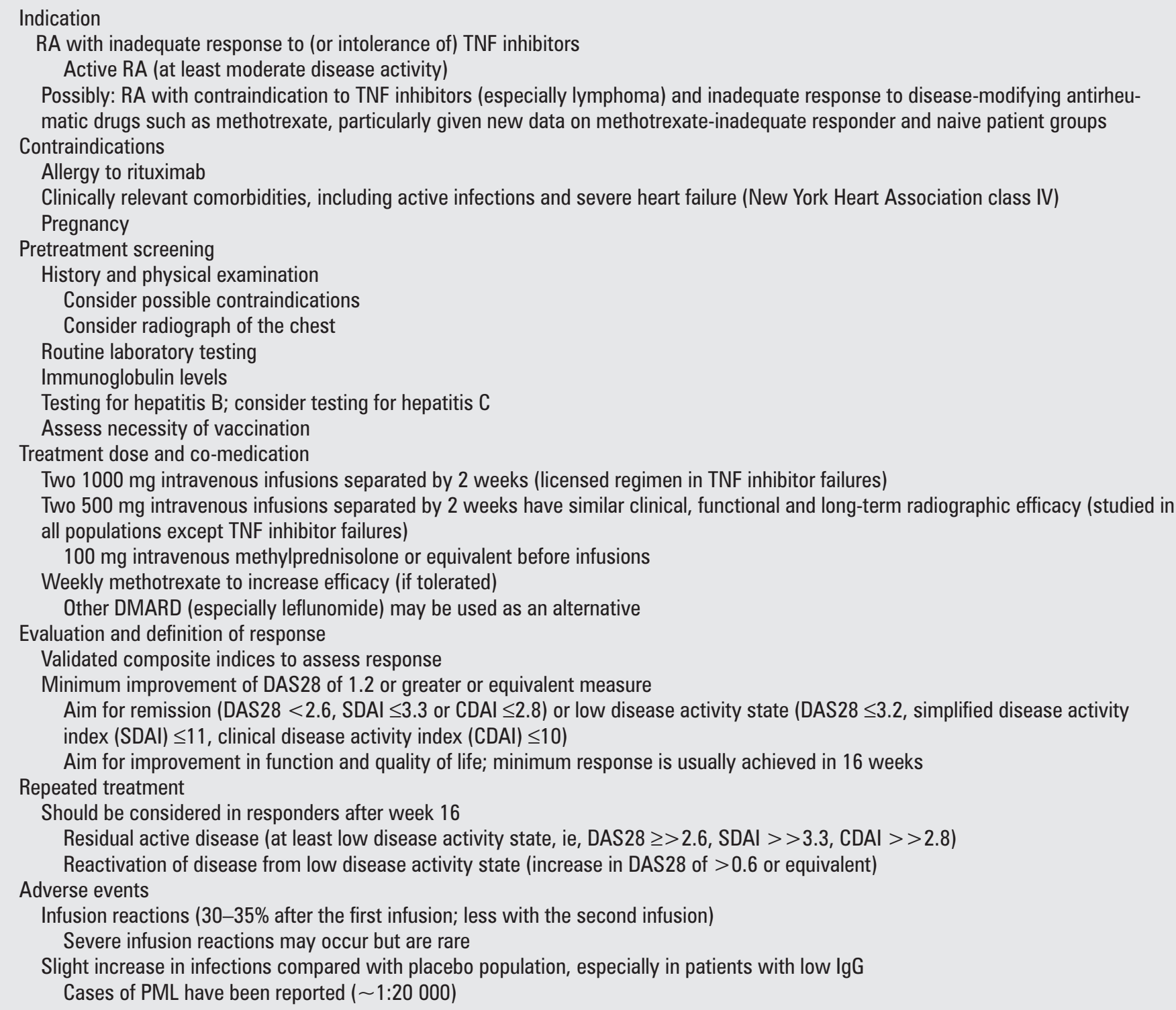

RCT and did not observe an increased risk of severe infections in RA patients treated with rituximab compared with placebo. ${ }^{103}$ Registry data have suggested that serious infections tend to occur in the initial months following rituximab, with predisposing factors comprising age, comorbidity, extra-articular involvement and low IgG. ${ }^{30}$

Hepatitis $B$ reactivation has been widely documented in the oncology literature60 62 highlighting the need to pre-screen patients (see the earlier section on 'Screening before initiating rituximab' with additional information provided in the supplementary material, available online only). Clinical trials in RA pre-screened patients for hepatitis B and C. Only one case of hepatitis $B$ reactivation in a patient with RA has been reported.52 Although the risk of hepatitis $C$ virus is not as clear54 we would also recommend pre-screening. Management in consultation with an expert gastroenterologist/hepatologist is advised.

In the clinical trial safety database, two cases of pulmonary tuberculosis have been reported; these appear to have been de novo infections (information from Roche). Among patients with
RA, three cases of tuberculosis and five cases with non-tuberculous mycobacterial infections haven been reported through a survey carried out in the USA and Canada. ${ }^{104}$ However, patients with records of tuberculosis have been treated with rituximab without any tuberculosis reactivation. ${ }^{30}$

In RA, six cases with progressive multifocal leukoencephalopathy (PML) have been reported (Roche data on file), including one case from the REFLEX trial ${ }^{3}$ giving an incidence of less than 1:20000 treated RA patients, compared with PML risks for patients with psoriasis treated with efalizumab (1:400) and patients with Crohn's disease and multiple sclerosis treated with natalizumab (1:1000). ${ }^{105} 106$ Most PML cases with RA had longstanding disease with numerous previous immunosuppressive treatments; only one patient had early RA naive to methotrexate and other DMARD. Currently, there is no identified risk profile for developing PML. Although the risk seems small, at this stage we would still advise clinicians to maintain vigilance. Additional background information on PML is provided in the supplementary material, available online only. 


\section{Immunoglobulin levels and infection risk}

The literature on patients with RA treated with rituximab describes low baseline levels of IgG, including before rituximab administration, as being associated with an increased risk of serious infections-these data come from a registry (hypo-IgG being present at baseline before rituximab in $5 \%$ of patients) as well as from compiled data from clinical trials. ${ }^{18}{ }^{30}$ In open extension studies, the occurrence of IgG levels below the lower limit of normal under rituximab treatment, especially sustained ( $\geq 4$ month) IgG below the lower limit, was associated with an increased risk of serious infections ${ }^{18}$ (data provided by Roche). In general, in addition to more traditional risk factors for infection such as age and concomitant glucocorticoid, patients with low IgG levels particularly need careful observation. Better definition and clarity on the management of low level IgG is still needed; nevertheless, from the data summarised to date, as recommended earlier, IgG should be monitored in patients treated with rituximab, particularly in those who demonstrate low baseline levels, with close monitoring particularly in higherrisk patient groups such as the older patient. The more frequent decreases in IgM, in contrast, have not been associated with increased rates of infections. After 1 year of treatment, levels of IgM were lower in patients receiving $2 \times 1000 \mathrm{mg}$ versus those receiving $2 \times 500 \mathrm{mg}$ (unpublished Roche data).

\section{Malignancy risk}

Although patients with previous malignancy are usually excluded in clinical trials; so far, no enhanced rates of solid malignancies or lymphoma under rituximab treatment have been observed ${ }^{18} 62$ (category Ia) ${ }^{107}$ (category III), with the exception of individuals with T-cell deficiency in HIV infec$\operatorname{tion}^{108}$ (category III). Therefore, to date, there have been no safety signals regarding malignancies; however, with respect to RA, larger databases on safety data are required before any firm conclusions can be drawn.

\section{Haematological side-effects}

In the oncology literature, late-onset neutrocytopaenia has been reported in up to $8 \%$ of patients treated with rituximab monotherapy and combination treatment and may occur up

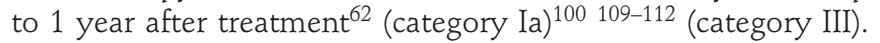
For unknown reasons, this complication is very rare in patients treated for autoimmune diseases. In some patients treatment with granulocyte colony-stimulating factor has been required. A multifactorial aetiology is likely to underlie the blood dyscrasia.

\section{Human antichimeric antibodies}

As rituximab is a chimeric antibody, human antichimeric antibodies (HACA) may occur. In the long-term, pooled safety analysis, $11 \%$ (273/2578 patients) were HACA positive on at least one visit. ${ }^{18}$ The rate of infusion reaction with re-treatment was similar in the HACA-positive compared with HACA-negative patients. AE related to HACA are rare, but a case of a severe allergic reaction was reported in which HACA apparently prevented B-cell depletion ${ }^{33}$ (category IV) (www.accessdata. fda.gov/scripts/cder/drugsatfda,www.ema.eu.int/humans/ Humans/EPAR/mabthera/mabthera). The development of HACA does not appear to influence the clinical efficacy of rituximab treatment. ${ }^{113}$

\section{Long-term safety of rituximab}

A recent pooled analysis of safety data from the rituximab in combination with methotrexate global clinical trial programme were based on 5013 patient-years of rituximab exposure $(n=2578$ having received at least one course of rituximab). ${ }^{18}$ The rate of
$\mathrm{AE}$ and serious events including infections and serious infections remained stable across several courses.

\section{ADDITIONAL ASPECTS TO BE CONSIDERED AND RESEARCH AGENDA}

It is evident from this document that several areas of future investigation and research are warranted. These are summarised in table 6 but are discussed in detail in the supplementary material, available online only. These relate particularly to mode of action, safety and efficacy issues; with respect to the latter, questions such as optimal dose regimen, direct comparison with other biological agents and indicators for retreatment require appropriate answers.

\section{CONCLUSION}

Additional data on rituximab in the management of RA have accumulated since publication of the first consensus statement and have provided further insights into its use (box 1). Benefit in earlier disease has been demonstrated together with novel radiographic information. It is now also firmly established that rituximab is effective primarily in seropositive RA. Recent studies have further supported the efficacy of reduced dosage and different regimens, although more work is needed to establish the optimal strategy. Safety data from rheumatology as well as oncology literature highlight the need for hepatitis screening as well as checking pretreatment immunoglobulin levels to identify patients possibly at greater risk of infection. Data thus far do not indicate the need for routine tuberculosis screening. As with other biological agents, the need for vaccination should be assessed. Safety concerns for very rare events such as PML have emerged. Ongoing evaluations should clarify the remaining open issues and ultimately lead to a more refined application of rituximab therapy.

Author affiliations ${ }^{1}$ Section of Musculoskeletal Diseases, Leeds Institute of Molecular Medicine, University of Leeds, Leeds, UK

${ }^{2}$ NIHR Leeds Musculoskeletal Biomedical Research Unit, Leeds Teaching Hospitals NHS Trust, Leeds, UK

${ }^{3}$ Department of Internal Medicine 3, Division of Rheumatology, Medical University of Vienna, Vienna, Austria

${ }^{4}$ Center for Rheumatic Diseases, Hietzing Hospital, Vienna, Austria

${ }^{5}$ Arthritis Care, UK

${ }^{6}$ Department of Rheumatology, Leiden University Medical Center, Leiden, The Netherlands

${ }^{7}$ Department of Rheumatology and Clinical Immunology, Humboldt University, Charite Hospital, Berlin, Germany

${ }^{8}$ Division of Rheumatology, Catholic University of the Sacred Heart, Rome, Italy ${ }^{9}$ Rheumatology Department, Hôpitaux Universitaires de Strasbourg, Université de Strasbourg, Strasbourg, France

${ }^{10}$ Institute of Cellular Medicine, Newcastle University Medical School, Newcastle upon Tyne, UK

${ }^{11}$ Department of Rheumatology, Diakonhjemmet Hospital, Oslo, Norway

${ }^{12}$ Institut Pour la Santé et la Recherche Médicale (INSERM) U 1012, Hôpital Bicêtre, Université Paris-Sud 11, Paris, France

${ }^{13}$ La Paz Hospital, Madrid, Spain

${ }^{14}$ Institute of Rheumatology and Clinic of Rheumatology Charles University, Prague, Czech Republic

${ }^{15}$ Division of Clinical Immunology and Rheumatology, Academic Medical Center/ University of Amsterdam, Amsterdam, The Netherlands

${ }^{16}$ Rheumatology Unit, Department of Medicine, Karolinska Institutet, Karolinska University Hospital, Solna, Sweden

Rituximab Consensus Expert Committee Jordi Carbonell Abello (Spain), Marwan Bukhari (UK), Harald Burkhardt (Germany), Bernard Combe (France), Juan-Jesus Gomez-Reino Carnota (Spain), Leonor Barile Fabris (Mexico), Lars Klareskog (Sweden), Jose Luis Marenco de la Fuente (Spain), Carlo-Maurizio Montecucco (Italy), Mikkel Ostergaard (Denmark), Eliseo Pascual Gomez (Spain), Raimon Sanmarti Sala (Spain), Hans-Peter Tony (Germany), Guido Valesini (Italy), Jaap van Laar (UK), Piet van Riel (The Netherlands).

Funding Hoffmann-La Roche provided an unrestricted educational grant to facilitate the development of this document. The views expressed in this guidance document 
including the final recommendations were not influenced by the sponsor and no representative of the sponsor was present in any of the discussion sessions.

Competing interests All participants except the patient representative have been active on advisory boards or participated in clinical trials by the sponsor. Professor Johannes Bijlsma was the handling editor.

Provenance and peer review Not commissioned; externally peer reviewed.

\section{REFERENCES}

1. Edwards JC, Szczepanski L, Szechinski J, et al. Efficacy of B-cell-targeted therapy with rituximab in patients with rheumatoid arthritis. N Engl J Med 2004;350:2572-81

2. Emery P, Fleischmann R, Filipowicz-Sosnowska A, et al. The efficacy and safety of rituximab in patients with active rheumatoid arthritis despite methotrexate treatment: results of a phase IIB randomized, double-blind, placebo-controlled, dose-ranging tria Arthritis Rheum 2006;54:1390-400.

3. Cohen SB, Emery P, Greenwald MW, et al. Rituximab for rheumatoid arthritis refractory to anti-tumor necrosis factor therapy: results of a multicenter, randomized, double-blind, placebo-controlled, phase III trial evaluating primary efficacy and safety at twenty-four weeks. Arthritis Rheum 2006;54:2793-806.

4. Smolen JS, Keystone EC, Emery P, et al. Consensus statement on the use of rituximab in patients with rheumatoid arthritis. Ann Rheum Dis 2007:66:143-50.

5. Shekelle PG, Woolf SH, Eccles M, et al. Clinical guidelines: developing guidelines. BMJ 1999:318:593-6.

6. Roitt I, Brostoff J, Male D. Immunology, 2nd edn. London: Gower Medical Publishing 1989.

7. Sell S, Max E. Immunology, Immunopathology and Immunity, 6th edn. Washington, DC: ASM Press, 2001:101-49.

8. Leandro MJ, Cambridge G, Ehrenstein MR, et al. Reconstitution of peripheral blood B cells after depletion with rituximab in patients with rheumatoid arthritis. Arthritis Rheum 2006:54:613-20.

9. Dass S, Rawstron AC, Vital EM, et al. Highly sensitive B cell analysis predicts response to rituximab therapy in rheumatoid arthritis. Arthritis Rheum 2008;58:2993-9

10. Nakou M, Katsikas G, Sidiropoulos P, et al. Rituximab therapy reduces activated $B$ cells in both the peripheral blood and bone marrow of patients with rheumatoid arthritis: depletion of memory B cells correlates with clinical response. Arthritis Res Ther 2009;11:R131.

11. Rehnberg M, Amu S, Tarkowski A, et al. Short- and long-term effects of anti-CD2O treatment on B cell ontogeny in bone marrow of patients with rheumatoid arthritis. Arthritis Res Ther 2009;11:R123.

12. Roll P, Palanichamy A, Kneitz $C$, et al. Regeneration of B cell subsets after transient $B$ cell depletion using anti-CD20 antibodies in rheumatoid arthritis. Arthritis Rheum 2006:54:2377-86

13. Teng YK, Levarht EW, Toes RE, et al. Residual inflammation after rituximab treatment is associated with sustained synovial plasma cell infiltration and enhanced B cell repopulation. Ann Rheum Dis 2009;68:1011-16.

14. Vos K, Thurlings RM, Wijbrandts CA, et al. Early effects of rituximab on the synovial cell infiltrate in patients with rheumatoid arthritis. Arthritis Rheum 2007:56:772-8.

15. Thurlings RM, Vos K, Wijbrandts CA, et al. Synovial tissue response to rituximab: mechanism of action and identification of biomarkers of response. Ann Rheum Dis 2008;67:917-25.

16. Kavanaugh A, Rosengren S, Lee SJ, et al. Assessment of rituximab's immunomodulatory synovial effects (ARISE trial). 1: Clinical and synovial biomarker results. Ann Rheum Dis 2008;67:402-8.

17. Popa C, Leandro MJ, Cambridge G, et al. Repeated B lymphocyte depletion with rituximab in rheumatoid arthritis over 7 yrs. Rheumatology (Oxford) 2007:46:626-30.

18. van Vollenhoven RF, Emery P, Bingham CO 3rd, et al. Longterm safety of patients receiving rituximab in rheumatoid arthritis clinical trials. J Rheumatol 2010;37:558-67.

19. Roll P, Dörner T, Tony HP. Anti-CD20 therapy in patients with rheumatoid arthritis: predictors of response and $B$ cell subset regeneration after repeated treatment. Arthritis Rheum 2008:58:1566-75.

20. Fleischmann RM. Progressive multifocal leukoencephalopathy following rituximab treatment in a patient with rheumatoid arthritis. Arthritis Rheum 2009:60:3225-8.

21. Genentech. Important Drug Warning Regarding Rituxan. San Francisco, CA Genentech, 2009

22. Keystone E, Fleischmann R, Emery P, et al. Safety and efficacy of additional courses of rituximab in patients with active rheumatoid arthritis: an open-label extension analysis. Arthritis Rheum 2007;56:3896-908

23. Rubbert-Roth A, Tak PP, Zerbini C, et al. Efficacy and safety of various repeat treatment dosing regimens of rituximab in patients with active rheumatoid arthritis: results of a phase III randomized study (MIRROR). Rheumatology (Oxford) 2010;49:1683-93.

24. Emery P, Deodhar A, Rigby WF, et al. Efficacy and safety of different doses and retreatment of rituximab: a randomised, placebo-controlled trial in patients who are biological naive with active rheumatoid arthritis and an inadequate response to methotrexate (Study Evaluating Rituximab's Efficacy in MTX iNadequate rEsponders (SERENE)). Ann Rheum Dis 2010;69:1629-35.
25. Tak PP, Rigby WF, Rubbert-Roth A, et al. Inhibition of joint damage and improved clinical outcomes with rituximab plus methotrexate in early active rheumatoid arthritis: the IMAGE trial. Ann Rheum Dis 2011:70:39-46.

26. Keystone E, Emery P, Peterfy CG, et al. Rituximab inhibits structural joint damage in patients with rheumatoid arthritis with an inadequate response to tumour necrosis factor inhibitor therapies. Ann Rheum Dis 2009;68:216-21.

27. Cohen SB, Keystone E, Genovese MC, et al. Continued inhibition of structural damage over 2 years in patients with rheumatoid arthritis treated with rituximab in combination with methotrexate. Ann Rheum Dis 2010;69:1158-61.

28. Pei SN, Chen $\mathrm{CH}$, Lee $\mathrm{CM}$, et al. Reactivation of hepatitis $\mathrm{B}$ virus following rituximabbased regimens: a serious complication in both $\mathrm{HBsAg-positive} \mathrm{and} \mathrm{HBsAg-negative}$ patients. Ann Hematol 2010;89:255-62.

29. Koo YX, Tan DS, Tan BH, et al. Risk of hepatitis B virus reactivation in patients who are hepatitis B surface antigen negative/antibody to hepatitis B core antigen positive and the role of routine antiviral prophylaxis. J Clin Oncol 2009;27:2570-1; author reply 2571-2.

30. Gottenberg JE, Ravaud P, Bardin T, et al. Risk factors for severe infections in patients with rheumatoid arthritis treated with rituximab in the autoimmunity and rituximab registry. Arthritis Rheum 2010;62:2625-32.

31. Wendler $\mathbf{J}$, Sorensen $H$, Tony $H$, et al. Effectiveness and safety of rituximab (RTX) monotherapy compared to RTX-combination therapy with methotrexate or leflunomide in the German RTX treatment of active rheumatoid arthritis in daily practice trial [abstract]. Ann Rheum Dis 2009:68(Suppl 3):76.

32. Gabay C, Chatzidionysiou K, Nasonov E, et al. Effectiveness of different DMARD co-therapies in rituximab-treated rheumatoid arthritis patients - results of a one-year follow-up study from the CERRERA collaboration. Ann Rheum Dis 2010;69(Suppl 3):68.

33. Rituximab. Full Prescribing Information. 2006. http://www.gene.com/gene/products/ information/oncology/rituxan/insert.jsp (accessed 4 Nov 2006).

34. Wendler J, Tony H, Krause A, et al. The German rituximab treatment of active rheumatoid arthritis in daily practice trial: second interim analysis of effectiveness and safety after 15 months [abstract]. Ann Rheum Dis 2008;67(Suppl II):340.

35. Yocum D, Rahman MU, Han C, et al. Infliximab induces disease remission in patients with rheumatoid arthritis: results from START clinical trial [abstract]. Arthritis Rheum 2005; 52:S140

36. Mease PJ, Cohen S, Gaylis NB, et al. Efficacy and safety of retreatment in patients with rheumatoid arthritis with previous inadequate response to tumor necrosis factor inhibitors: results from the SUNRISE trial. J Rheumatol 2010;37:917-27.

37. Cohen S, Dougados M, Genovese MC, et al. Consistent inhibition of structural damage progression by rituximab in medically important subgroups of patients with an inadequate response to TNF inhibitors: week 56 REFLEX results [abstract]. Ann Rheum Dis 2007;66(Suppl II):428.

38. Isaacs $\mathbf{J}$, Olech E, Tak P, et al. Autoantibody-positive rheumatoid arthritis (RA) patients (PTS) have enhanced clinical response to rituximab (RTX) when compared with seronegative patients. Ann Rheum Dis 2009:68(Suppl 3):442.

39. Van Vollenhoven R, Chatzidionysiou S, Nasonov E, et al. Six-month results from the Collaborative European REgistries for Rituximab in Rheumatoid Arthritis (CERERRA). Efficacy of rituximab is highest in RF-positive patients and in those who failed at most one prior anti-TNF. Arthritis Rheum 2009;60(Suppl):S1671.

40. Van Vollenhoven R, Chatzidionysiou K, Gabay C, et al. Rheumatoid factor predicts response to rituximab in a European registry-based cohort: 6-month results from the collaborative European registries for rituximab in rheumatoid arthritis (CERERRA) [abstract]. Ann Rheum Dis 2009;68(Suppl 3):579.

41. Strangfeld A, Eveslage M, Kekow J, et al. Effectiveness of treatment with rituximab depends on autoantibody status - results from 2 years of experience in the German biologics register RABBIT [abstract]. Arthritis Rheum 2009:60:S1695.

42. Van Vollenhoven RF, Chatzidionysiou K, Gabay C, et al. Rheumatoid factor predicts response to rituximab in a European registry-based cohort: 6-month results from the collaborative European registries for rituximab in rheumatoid arthritis (CERRERA). Ann Rheum Dis 2010;68(Suppl 3):579.

43. Silverman GJ, Schwartzman S, Townsend M, et al. Identification of biomarkers for enhanced benefit to rituximab in rheumatoid arthritis: role of autoantibodies and inflammatory markers [abstract]. Arthritis Rheum 2009;60:S1680.

44. Quartuccio L, Fabris M, Salvin S, et al. Rheumatoid factor positivity rather than anti-CCP positivity, a lower disability and a lower number of anti-TNF agents failed are associated with response to rituximab in rheumatoid arthritis. Rheumatology (Oxford) 2009;48:1557-9.

45. Dass S, Vital EM, Emery P. Development of psoriasis after B cell depletion with rituximab. Arthritis Rheum 2007;56:2715-18.

46. Smolen JS, Aletaha D, Bijlsma JW, et al. Treating rheumatoid arthritis to target: recommendations of an international task force. Ann Rheum Dis 2010:69:631-7.

47. Smolen JS, Landewé R, Breedveld FC, et al. EULAR recommendations for the management of rheumatoid arthritis with synthetic and biological disease-modifying antirheumatic drugs. Ann Rheum Dis 2010;69:964-75.

48. Aletaha D, Smolen JS. The Simplified Disease Activity Index (SDAl) and Clinical Disease Activity Index (CDAl) to monitor patients in standard clinical care. Best Pract Res Clin Rheumatol 2007:21:663-75.

49. Aletaha $\mathbf{D}$, Smolen JS. The definition and measurement of disease modification in inflammatory rheumatic diseases. Rheum Dis Clin North Am 2006;32:9-44; vii. 
50. Gottenberg JE, Mariette X, Ravaud P, et al. Predictive risk factors of severe infections in RA patients treated with rituximab in real life: results from the AIR registry [abstract]. Arthritis Rheum 2009;60:S1703.

51. Vander Cruyssen B, Durez P, Westhovens R, et al. The Belgian MIRA (MabThera in Rheumatoid Arthritis) registry: clues for the optimization of rituximab treatment strategies. Arthritis Res Ther 2010;12:R169.

52. Pyrpasopoulou A, Douma S, Vassiliadis T, et al. Reactivation of chronic hepatitis $B$ virus infection following rituximab administration for rheumatoid arthritis. Rheumatol Int 2011;31:403-4.

53. Dizdar 0, Tapan U, Aksoy S, et al. Liver dysfunction after chemotherapy in lymphoma patients infected with hepatitis C. Eur J Haematol 2008;80:381-5.

54. Ennishi D, Yokoyama $\mathrm{M}$, Terui $\mathrm{Y}$, et al. Does rituximab really induce hepatitis $\mathrm{C}$ virus reactivation? J Clin Oncol 2008;26:4695-6; author reply 4696.

55. Liaw YF, Leung N, Kao JH, et al. Asian-Pacific consensus statement on the management of chronic hepatitis B: a 2008 update. Hepatol Int 2008;2:263-83.

56. Lok AS, McMahon BJ. Chronic hepatitis B. Hepatology 2007;45:507-39.

57. Weinbaum CM, Williams I, Mast EE, et al. Recommendations for identification and public health management of persons with chronic hepatitis B virus infection. MMWR Recomm Rep 2008;57:1-20.

58. Ferri C, Govoni M, Calabrese L. The A, B, Cs of viral hepatitis in the biologic era. Curr Opin Rheumatol 2010;22:443-50.

59. Yazdany J, Calabrese L. Preventing hepatitis B reactivation in immunosuppressed patients: is it time to revisit the guidelines? Arthritis Care Res (Hoboken) 2010;62:585-9.

60. Artz AS, Somerfield MR, Feld JJ, et al. American Society of Clinical Oncology provisional clinical opinion: chronic hepatitis B virus infection screening in patients receiving cytotoxic chemotherapy for treatment of malignant diseases. J Clin Oncol 2010;28:3199-202.

61. Jick SS, Lieberman ES, Rahman MU, et al. Glucocorticoid use, other associated factors, and the risk of tuberculosis. Arthritis Rheum 2006;55:19-26.

62. Kimby E. Tolerability and safety of rituximab (MabThera). Cancer Treat Rev 2005;31:456-73.

63. van Assen S, Holvast A, Benne CA, et al. Humoral responses after influenza vaccination are severely reduced in patients with rheumatoid arthritis treated with rituximab. Arthritis Rheum 2010;62:75-81.

64. Bingham CO III, Looney RJ, Deodhar A, et al. Immunization responses in rheumatoid arthritis patients treated with rituximab: results from a controlled clinical trial. Arthritis Rheum 2010;62:64-74.

65. van Assen S, Agmon-Levin N, Elkayam 0, et al. EULAR recommendations for vaccination in adult patients with autoimmune inflammatory rheumatic diseases. Ann Rheum Dis 2011:70:414-22.

66. Loveless JE, Olech E, Pritchard C, et al. An open-label, prospective study (SUNDIAL) of the safety of rituximab in combination with disease-modifying anti-rheumatic drugs in patients with active rheumatoid arthritis (SUNDIAL). Arthritis Rheum 2009:60:S1660.

67. Greenwald M, Kaine JL, Sweetser MT, et al. Safety of rituximab in combination with a TNF inhibitor and methotrexate in patients with active rheumatoid arthritis: results from a randomized controlled trial (TAME). Arthritis Rheum 2009;60:S1957.

68. van der Kolk LE, Grillo-López AJ, Baars JW, et al. Treatment of relapsed B-cell non-Hodgkin's lymphoma with a combination of chimeric anti-CD20 monoclonal antibodies (rituximab) and G-CSF: final report on safety and efficacy. Leukemia 2003:17:1658-64

69. Emery P, Mease P, Rubbert A, et al. Retreatment with rituximab (RTX) based on a treatment to target (TT) approach provides better disease control than treatment as needed (PRN) in patients with rheumatoid arthritis [abstract]. Arthritis Rheum 2009;60:S2013

70. Bastian H, Zinke S, Egerer K, et al. Effects of early rituximab retreatment in rheumatoid arthritis patients with an inadequate response after the first cycle: retrospective arthritis cohort study. J Rheumato/ 2010;37:1069-71.

71. Vital EM, Dass S, Rawstron AC, et al. Management of nonresponse to rituximab in rheumatoid arthritis: predictors and outcome of re-treatment. Arthritis Rheum 2010;62:1273-9.

72. Thurlings RM, Vos K, Gerlag DM, et al. Disease activity-guided rituximab therapy in rheumatoid arthritis: the effects of re-treatment in initial nonresponders versus initial responders. Arthritis Rheum 2008;58:3657-64.

73. Finckh A, Ciurea A, Brulhart L, et al. B cell depletion may be more effective than switching to an alternative anti-tumor necrosis factor agent in rheumatoid arthritis patients with inadequate response to anti-tumor necrosis factor agents. Arthritis Rheum 2007:56:1417-23.

74. Chatzidionysiou S, Carli C, Van Vollenhoven R. Rituximab versus anti-TNF in patients who have previously failed one or more anti-TNFs in an observational cohort: the SARASTRA study. Ann Rheum Dis 2009;68(Suppl 3):445.

75. Buch M, Dass S, Vital E, et al. Is switching to rituximab more effective than switching to an alternative tumour necrosis factor blocking therapy (TNF-BT) in patients with rheumatoid arthritis (RA) who have failed previous TNF-BT? - single-centre cohort experience. Ann Rheum Dis 2009;68:574.

76. Gomez-Reino J, Sanmarti R, Azpeitia D. Rituximab compared with further tumour necrosis factor antagonist therapy in rheumatoid arthritis patients who had previously failed TNF antagonist therapy: results of a prospective, observational study [abstract] Ann Rheum Dis 2009;68(Suppl 3):442.

77. Chatzidionysiou S, Carli C, van Vollenhoven R. Rituximab versus anti-TNF in patients who have previously failed one or more anti-TNFs in an observational cohort - the SARASTRA study. Arthritis Rheum 2009;60(Suppl):1025

78. Nam JL, Winthrop KL, van Vollenhoven RF, et al. Current evidence for the management of rheumatoid arthritis with biological disease-modifying antirheumatic drugs: a systematic literature review informing the EULAR recommendations for the management of RA. Ann Rheum Dis 2010;69:976-86.

79. Breedveld F, Genovese MC, Emery P, et al. Safety of TNF inhibitors in rheumatoid arthritis patients previously treated with rituximab [abstract]. Ann Rheum Dis 2006:65(Suppl II):178.

80. Genovese MC, Breedveld FC, Emery P, et al. Safety of biological therapies following rituximab treatment in rheumatoid arthritis patients. Ann Rheum Dis 2009:68:1894-7.

81. Gottenberg J, Flipo R, Cantagrel A, et al. Switching from rituximab to abatacept: tolerance data of 179 patients prospectively followed up in the 'Orencia in Rheumatoid Arthritis' (ORA) registry. Ann Rheum Dis 2010;69(Suppl 3):385.

82. Schoels M, Wong J, Scott DL, et al. Economic aspects of treatment options in rheumatoid arthritis: a systematic literature review informing the EULAR recommendations for the management of rheumatoid arthritis. Ann Rheum Dis 2010;69:995-1003.

83. Kielhorn A, Porter D, Diamantopoulos A, et al. UK cost-utility analysis of rituximab in patients with rheumatoid arthritis that failed to respond adequately to a biologic disease-modifying antirheumatic drug. Curr Med Res Opin 2008;24:2639-50.

84. Lindgren $\mathbf{P}$, Geborek P, Kobelt G. Modeling the cost-effectiveness of treatment of rheumatoid arthritis with rituximab using registry data from Southern Sweden. Int J Technol Assess Health Care 2009;25:181-9.

85. Launois R, Payet S, Saidenberg-Kermanac'h N, et al. Budget impact model of rituximab after failure of one or more TNFalpha inhibitor therapies in the treatment of rheumatoid arthritis. Joint Bone Spine 2008;75:688-95.

86. Marks SD, Patey S, Brogan PA, et al. B lymphocyte depletion therapy in children with refractory systemic lupus erythematosus. Arthritis Rheum 2005;52:3168-74.

87. Marks SD, Tullus K. Successful outcomes with rituximab therapy for refractory childhood systemic lupus erythematosus. Pediatr Nephrol 2006;21:598-9.

88. El-Hallak M, Binstadt BA, Leichtner AM, et al. Clinical effects and safety of rituximab for treatment of refractory pediatric autoimmune diseases. J Pediatr 2007; 150:376-82

89. Feito JG, Pereda CA. Rituximab therapy produced rapid and sustained clinical improvement in a patient with systemic onset juvenile idiopathic arthritis refractory to TNF alpha antagonists. J Clin Rheumatol 2009;15:363-5.

90. Kasher-Meron M, Uziel Y, Amital H. Successful treatment with B-cell depleting therapy for refractory systemic onset juvenile idiopathic arthritis: a case report. Rheumatology (Oxford) 2009;48:445-6.

91. Narváez J, Díaz-Torné C, Juanola X, et al. Rituximab therapy for refractory systemiconset juvenile idiopathic arthritis. Ann Rheum Dis 2009;68:607-8.

92. Kuek A, Hazleman BL, Gaston JH, et al. Successful treatment of refractory polyarticular juvenile idiopathic arthritis with rituximab. Rheumatology (Oxford) 2006;45:1448-9.

93. Chakravarty EF, Murray ER, Kelman A, et al. Blood 2011;117:1499-506.

94. Østensen M, Förger F. Management of RA medications in pregnant patients Nat Rev Rheumatol 2009:5:382-90

95. Al Zahrani A, Ibrahim N, Al Eid A. Rapid infusion rituximab changing practice for patient care. J Oncol Pharm Pract 2009;15:183-6.

96. Chiang J, Chan A, Shih V, et al. A prospective study to evaluate the feasibility and economic benefits of rapid infusion rituximab at an Asian cancer center. Int J Hematol 2010;91:826-30

97. Provencio $\mathbf{M}$, Cerdeira S, Bonilla F, et al. Rapid-infusion rituximab in lymphoma treatment. Ann Oncol 2006;17:1027-8.

98. Salar A, Casao D, Cervera M, et al. Rapid infusion of rituximab with or without steroid-containing chemotherapy: 1-yr experience in a single institution. Eur J Haematol 2006; 77:338-40.

99. Tuthill M, Crook T, Corbet T, et al. Rapid infusion of rituximab over $60 \mathrm{~min}$. Eur J Haematol 2009:82:322-5.

100. Boué F, Gabarre J, Gisselbrecht C, et al. Phase II trial of CHOP plus rituximab in patients with HIV-associated non-Hodgkin's lymphoma. J Clin Oncol 2006;24:4123-8.

101. Bermúdez A, Marco F, Conde $\mathrm{E}$, et al. Fatal visceral varicella-zoster infection following rituximab and chemotherapy treatment in a patient with follicular lymphoma. Haematologica 2000;85:894-5.

102. Strangfeld A, Listing J, Herzer P, et al. Risk of herpes zoster in patients with rheumatoid arthritis treated with anti-TNF-alpha agents. JAMA 2009;301:737-44

103. Salliot C, Dougados M, Gossec L. Risk of serious infections during rituximab, abatacept and anakinra treatments for rheumatoid arthritis: meta-analyses of randomised placebo-controlled trials. Ann Rheum Dis 2009;68:25-32.

104. Winthrop KL, Yamashita S, Beekmann SE, et al. Mycobacterial and other serious infections in patients receiving anti-tumor necrosis factor and other newly approved biologic therapies: case finding through the Emerging Infections Network. Clin Infect Dis 2008:46:1738-40. 
105. Carson KR, Evens AM, Richey EA, et al. Progressive multifocal leukoencephalopathy after rituximab therapy in HIV-negative patients: a report of 57 cases from the Research on Adverse Drug Events and Reports project. Blood 2009; 113:4834-40.

106. Carson KR, Focosi D, Major E0, et al. Monoclonal antibody-associated progressive multifocal leucoencephalopathy in patients treated with rituximab, natalizumab, and efalizumab: a review from the Research on Adverse Drug Events and Reports (RADAR) Project. Lancet Oncol 2009;10:816-24.

107. Hainsworth JD. Safety of rituximab in the treatment of B cell malignancies: implications for rheumatoid arthritis. Arthritis Res Ther 2003:5(Suppl 4):S12-16.

108. Spina M, Jaeger U, Sparano JA, et al. Rituximab plus infusional cyclophosphamide, doxorubicin, and etoposide in HIV-associated non-Hodgkin lymphoma: pooled results from 3 phase 2 trials. Blood 2005;105:1891-7.
109. Dunleavy K, Hakim F, Kim HK, et al. B-cell recovery following rituximab-based therapy is associated with perturbations in stromal derived factor-1 and granulocyte homeostasis. Blood 2005;106:795-802.

110. Lai GG, Lim ST, Tao M, et al. Late-onset neutropenia following RCHOP chemotherapy in diffuse large B-cell lymphoma. Am J Hematol 2009;84:414-17.

111. Marotte H, Paintaud G, Watier $H$, et al. Rituximab-related late-onset neutropenia in a patient with severe rheumatoid arthritis. Ann Rheum Dis 2008;67:893-4.

112. Nitta $\mathbf{E}$, Izutsu K, Sato T, et al. A high incidence of late-onset neutropenia following rituximab-containing chemotherapy as a primary treatment of CD20-positive B-cell Jymphoma: a single-institution study. Ann Oncol 2007:18:364-9.

113. Thurlings RM, Teng 0 , Vos $K$, et al. Clinical response, pharmacokinetics, development of human anti-chimaeric antibodies, and synovial tissue response to rituximab treatment in patients with rheumatoid arthritis. Ann Rheum Dis 2010;69:409-12. 